\title{
Semi-purified glycerin in the meat quails feeding
}

\section{Glicerina semipurificada na alimentação de codornas de corte ${ }^{1}$}

\author{
Tiago Junior Pasquetti ${ }^{2}$; Antonio Claudio Furlan ${ }^{3}$; Ana Paula Silva Ton ${ }^{4}$; \\ Elias Nunes Martins; ${ }^{3}$; Vittor Zancanela²; Daiane de Oliveira Grieser²; \\ Eliany Batista ${ }^{2}$; Paulo Cesar Pozza ${ }^{3}$
}

\begin{abstract}
Three experiments were conducted to determine the nutritional value of semi-purified glycerin (SG), and its economic feasibility for use in meat quail feed. Its effect on the performance, body chemical composition, and carcass yield were assessed. In experiment 1, 22-day-old quails, were housed in metabolic cages, distributed in a completely randomized design (CRD), with three treatments, five replicates, and five birds per repetition, using 75 quails in total. Treatments consisted of a reference diet (RD) and two test diets (TD) in which $8 \%$ and $12 \%$ SG replaced the RD. The estimated value of nitrogen-corrected apparent metabolizable energy (AMEn) for SG was 2,476 kcal $/ \mathrm{kg}$. In experiment 2, 1320 quails (55 quails in each box) were distributed in a CRD with six treatments and four replicates. The treatments consisted of a control diet, based on corn and soybean meal, and five diets with increasing levels of SG $(3 \%, 6 \%, 9 \%, 12 \%$, and $15 \%)$. There were no effects of SG on the performance variables. The cost per kilogram of live weight produced increased linearly $(P<0.05)$ with the percentage of SG in the diet. The performance data suggest that SG may be included in up to $15 \%$ of the diet in 1- to 14-day-old quails. In experiment 3, 1032 quails (43 quails in each box) were distributed under the same conditions as in experiment 2. SG influenced linearly the litter moisture $(\mathrm{P}<0,05)$ and body biomass accumulated (BBA), and had a quadratic effect on feed conversion ratio and $\mathrm{BBA}(\mathrm{P}<0,05)$. The cost per kilogram of live weight produced increased linearly $(P<0.05)$ with the percentage of SG in the diet. Therefore, SG may be used to make-up $10 \%$ of the diet of 15-35-day-old quail.
\end{abstract}

Key words: Coturnix coturnix sp., performance, metabolizable energy, carcass yield, economic feasibility

\section{Resumo}

Três experimentos foram conduzidos para determinar o valor nutritivo da glicerina semipurificada (GS) e verificar seu efeito sobre o desempenho, composição química corporal, características de carcaça e a viabilidade econômica de sua utilização em dietas para codornas de corte. No Experimento 1 foram utilizadas 75 codornas, com 22 dias de idade, alojadas em gaiolas de metabolismo, distribuídas em um delineamento inteiramente casualizado (DIC), com 3 tratamentos e 5 repetições, com 5 aves por repetição. Os tratamentos consistiram de uma ração referência (RR) e duas rações teste (RT), sendo que a GS substituiu a RR em níveis de 8 e $12 \%$. O valor estimado de EMAn para a GS foi de $2.476 \mathrm{kcal} / \mathrm{kg}$ de matéria natural. No Experimento 2 foram utilizadas 1.320 codornas de corte ( 55 aves em cada boxe),

${ }^{1}$ Parte da Dissertação de Mestrado do primeiro autor.

2 Discentes do Curso de Doutorado no Programa de Pós-Graduação em Zootecnia, PPZ, Universidade Estadual de Maringá, UEM, Maringá, PR, Brasil. E-mail: pasquettizoo@yahoo.com.br; vitorzoo@hotmail.com; dane_oliveira@hotmail.com; eliany_ batista@hotmail.com

3 Profs., Dept ${ }^{\circ}$ de Zootecnia, UEM, Maringá, PR, Brasil. E-mail: acfurlan@uem.br; enmartins@uem.br; pcpozza@uem.br

${ }^{4}$ Prof ${ }^{a}$, Instituto de Ciências Agrárias e Ambientais, ICAA, Universidade Federal de Mato Grosso, UFMT, Sinop, MT, Brasil. E-mail: anatonn4@hotmail.com

* Author for correspondence 
distribuídas em DIC, com seis tratamentos e quatro repetições. Os tratamentos foram constituídos por uma dieta controle, a base de milho e farelo de soja, e cinco dietas com níveis crescentes de inclusão de GS $(3,6,9,12$, e 15\%). Não foram observados efeitos da GS sobre as variáveis de desempenho. $\mathrm{O}$ custo por quilograma de peso vivo produzido aumentou linearmente $(\mathrm{P}<0,05)$ com a inclusão dos níveis de GS. Considerando os dados de desempenho, conclui-se que a GS pode ser incluída até o nível de $15 \%$, na fase de 1 a 14 dias. No Experimento 3 foram utilizadas 1.032 codornas (43 aves em cada boxe), distribuídas sob as mesmas condições do Experimento 2. A glicerina semipurificada influenciou de forma linear $(\mathrm{P}<0,05)$ a umidade da cama e a biomassa corporal acumulada (BCA), e, de forma quadrática a conversão alimentar e a $\mathrm{BCA}(\mathrm{P}<0,05)$. $\mathrm{O}$ custo por quilograma de peso vivo produzido aumentou linearmente $(\mathrm{P}<0,05)$ com a inclusão dos níveis de GS. Considerando os dados de desempenho, a GS pode ser incluída até o nível de $10 \%$, na fase de 15 a 35 dias.

Palavras-chave: Coturnix coturnix sp., desempenho, energia metabolizável, rendimento de carcaça, viabilidade econômica

\section{Introduction}

The cost of feeding accounts for most of the costs associated with animal production. This encourages the search for new foods that can reduce costs while effectively replacing corn or soybean meal, as these represent the most common ingredients used in feed formulations. Murakami and Furlan (2002) suggested the use of alternative feedstuffs in diets for broilers and laying hens. However, for quail feed, such information is scarce, considering that these birds exhibit physiological and behavioral characteristics that differ from those of broilers and laying hens, which may affect feed efficiency and productivity. Thus, food may be metabolized differently depending on anatomical and physiological differences.

By-products or residues from the industrial processing of agricultural products have attracted the attention of researchers (GOMES et al., 2006). Glycerin is an agricultural by-product and its use in animal nutrition is being studied. Glycerin is derived from biodiesel production, and semipurified glycerin (SG) can be obtained from renewable sources including vegetable oils or animal fats. Glycerin is a rich source of energy and can be efficiently metabolized by animals when it is incorporated into diets at the correct levels. However, as glycerin can be derived from several plants that produce biodiesel, and use different raw materials for its production, glycerin may vary in its chemical composition having a direct influence on its energy values. Crude glycerin is the first by-product generated from biodiesel production, and has a high concentration of fatty acids. For this reason, in some companies, crude glycerin is subjected to the transesterification process, in which most of the remaining fatty acids are removed, resulting in the production of SG. Thus, SG has a low fatty acid content, and significant levels of sodium/potassium and methanol/ethanol, derived from the catalysts (sodium chloride/potassium and methanol/ethanol) used in the biodiesel production process. Due to SG having a yellowish color, it is also called blonde glycerin. At room temperature, SG is in a liquid state, while the crude glycerin, due to a higher amount of saturated fatty acids, can pass into a solid state at lower temperature conditions.

Due to the large capacity for biodiesel production in Brazil, there is some concern about excess byproducts. Thus, the use of glycerin as an energy source in animal feeds may be a viable alternative, with the potential to reduce environmental contamination and thus being more environmentally sustainable.

Cerrate et al. (2006) showed that glycerin could be included to account for up to $5 \%$ of the diets of broilers without impairing their performance. However, the inclusion of $10 \%$ glycerin in the diet resulted in a decrease in feed intake and decreased performance. 
Evaluating the addition of $10 \%$ crude glycerin (81.47\% glycerol, $153 \mathrm{ppm}$ methanol and 2.4\% sodium) for broilers, over two periods (1-21 and 1-42 days), Menten et al. (2008) found a significant improvement in the first period, when the glycerin diet was compared with the control diet. On the other hand, from day 1 to 42, the authors found no difference between the glycerin and control diets.

Batista et al. (2013), working with inclusion levels of vegetable semi-purified glycerin $(4 \%, 8 \%$, $12 \%$, and $16 \%$ ), showed that glycerin can be used to make up to $16 \%$ of diets, noting that its use will depend on the prices of other ingredients.

Although glycerin has been widely used as an energy source in animal feed, there have only been a few studies involving quail. Thus, the aim of the current study was to evaluate the performance, chemical body composition, carcass traits, litter moisture, and economic feasibility of including SG in the diets of quails aged 1-14, and 15-35-days old.

\section{Materials and Methods}

Three experiments were carried out in the Fazenda Experimental de Iguatemi (FEI), at Universidade Estadual de Maringá/UEM.

1. Experiment 1: A total of 75 meat quails (Coturnix coturnix sp.), 22 days old, were housed in galvanized wire cages (five birds per cage) containing nipple drinkers and trough type feeders. The birds were allocated in a completely randomized design, with three treatments and five replicates. Treatments consisted of a basal diet (BD), formulated with corn and soybean meal (Table 1), in which the chemical composition of ingredients was obtained from Rostagno et al. (2005), and two test diets (TD), wherein glycerin was included at levels of $8 \%$ and $12 \%$. The lysine and energy requirements determined by Scherer (2009) and calcium and phosphorus levels determined by Silva et al. (2009) were used.
The experimental period was 10 days, which consisted of five days to allow birds to adapt to the cages and feed, and five for total excreta collection. In this period, the birds received feed and water ad libitum. In order to calculate the average feed intake, the diets were weighed at the beginning and end of the total collection period.

To determine the start and end of the excreta collection period, ferric oxide $(2 \%)$ was used. The excreta were collected twice daily and then grouped by experimental unit, packed in plastic bags, and stored in the freezer until the end of the total collection period. Subsequently the samples were thawed, homogenized, weighed, and dried in a forced air oven for $72 \mathrm{~h}$ at $55^{\circ} \mathrm{C}$. The analysis of dry matter (DM), crude protein (CP), mineral matter (MM), organic matter (OM), and gross energy (GE) of excreta and diets, were performed as described by Silva and Queiroz (2005).

The values of nitrogen-corrected apparent metabolizable energy (AMEn), as well as the metabolizability coefficients (MC) of GE, DM, OM, and $\mathrm{EE}$ were determined according to the equations proposed by Matterson et al. (1965). These values were subjected to regression analysis to estimate the energy value considering the consumption of AMEn, related to the consumption of SG of the experimental units (Table 2), under the restriction of zero intercept (NETER; WASSERMAN, 1974).

2. Experiment 2 and 3: In experiment two, from 1 to 14 days, 1320 unsexed one-day-old quails (Coturnix coturnix sp.), were used. The birds were housed in a conventional barn with 24 pens of 2.5 $\mathrm{m}^{2}$ each, in which rice hulls were used as litter. In all pens, the same amount (about $10 \mathrm{~cm}$ ) of litter was used. A completely randomized design was used, with six treatments and four replicates with 55 quails per experimental unit. In experiment three, from 15 to 35 days old, 1032 quails were housed under the same conditions as in experiment two, with 43 birds per pen. 
Table 1. Chemical and energetic composition of basal diet for meat quails in the growth phase.

\begin{tabular}{lc}
\hline Ingredient (\%) & Amount $(\mathrm{kg})$ \\
\hline Corn & 53.56 \\
Soybean meal (45\%) & 38.87 \\
Soybean oil & 3.00 \\
Dicalcium phosphate & 1.60 \\
DL-methionine & 0.93 \\
L -lysine HCL & 0.81 \\
Salt & 0.40 \\
Limestone & 0.28 \\
Premix ${ }^{1}$ & 0.35 \\
L-threonine & 0.19 \\
Antioxidant (BHT) ${ }^{2}$ & 0.01 \\
\hline Total & 100.00 \\
\hline Calculated content & \\
\hline Crude protein (\%) & 23.50 \\
Calcium (\%) & 0.61 \\
Available phosphorus (\%) & 0.41 \\
Metabolizable energy (ME) (kcal/kg) & 3,036 \\
Digestible methionine + cystine (\%) & 1.52 \\
Digestible lysine (\%) & 1.73 \\
Digestible threonine (\%) & 0.93 \\
Digestible tryptophan (\%) & 0.25 \\
Sodium (\%) & 0.18 \\
\hline
\end{tabular}

${ }^{1}$ Vitamin/mineral supplementation (guaranteed levels per kg of product); Vit. A, 4,500,000 UI; Vit. D3, 1,250,000 UI; Vit. E, 4000 mg; Vit. B1, 278 mg; Vit. B2, 2.000 mg; Vit. B6, 525 mg; Vit. B12, 5000 mcg; Vit. K3, 1007 mg; Calcium Pantothenate, 4000 mg; Niacin, 10,000 mg; Choline, $140.000 \mathrm{mg}$; Antioxidant, $5000 \mathrm{mg}$; Zinc, 31,500 mg; Iron, 24,500 mg; Manganese, 38,750 mg; Copper, $7656 \mathrm{mg}$; Cobalt, $100 \mathrm{mg}$; Iodine, $484 \mathrm{mg}$; Selenium, $127 \mathrm{mg}$; ${ }^{2} \mathrm{BHT}$ (Butylated hydroxytoluene).

Source: Elaboration of the authors.

Table 2. Data used to estimate the nitrogen-corrected apparent metabolizable energy (AMEn) of semi-purified glycerin (SG).

\begin{tabular}{ccccc}
\hline SG levels (\%) & DMI ${ }^{1}(\mathrm{Kg})$ & Glycerin intake $(\mathrm{Kg})$ & AMEn $(\mathrm{kcal} / \mathrm{kg})^{*}$ & AMEn intake $(\mathrm{kcal} / \mathrm{kg})$ \\
\hline & 0.3888 & 0.0311 & 2,613 & 81.2824 \\
8 & 0.4606 & 0.0369 & 2,455 & 90.4549 \\
& 0.3380 & 0.0270 & 2,221 & 60.0674 \\
& 0.4361 & 0.0349 & 1,767 & 61.6575 \\
& 0.4326 & 0.0346 & 1,922 & 66.5203 \\
\hline \multirow{3}{*}{12} & 0.3602 & 0.0432 & 2,797 & 120.9043 \\
& 0.4046 & 0.0486 & 3,218 & 156.2640 \\
& 0.3551 & 0.0426 & 2,286 & 104.4372 \\
& 0.3893 & 0.0467 & 2,228 & 111.7756 \\
\hline
\end{tabular}

* Values obtained according to Matterson et al. (1965); DMI: Dry matter intake.

Source: Elaboration of the authors. 
The treatments (Table 3) consisted of a control diet (CD), based on corn and soybean meal, and five diets with increasing levels of SG $(3 \%, 6 \%$, $9 \%, 12 \%$, and $15 \%$ ). The AMEn of SG, used for the formulations of feed performance, was 2,476 kcal/ $\mathrm{kg}$, as determined in Experiment 1.

The weight gain (WG) was determined by the difference between the mean final body weight and the initial body weight of quails in each experimental unit. The feed intake was determined by the difference between the diet provided and the leftover feed. The FCR was calculated by the difference between feed intake and $\mathrm{WG}$, and the BBA was calculated as a function of WG compared to the initial weight of the quails evaluated at the beginning of each stage. Mortalities were recorded daily and leftover feed was weighed and used to correct for feed intake.

At the end of the experimental period, litter samples were collected from all pens at three distinct points, avoiding the places next to feeders and nipple drinkers. The samples were identified, packed in plastic bags, and homogenized for further analysis of dry matter.

To determine the chemical body composition, five full quails per experimental unit at 14 days of age, and three quails at day 35 were used. After six hours of fasting, they were euthanized by decapitation between the occipital bone and atlas using scissors.

The quails (with feathers and viscera) were ground in an industrial meat grinder. The samples were weighed and homogenized, and placed in a forced air oven at $55^{\circ} \mathrm{C}$, for $72 \mathrm{~h}$ to perform the predrying, and were subsequently ground for analytical measurements. The chemical composition analysis of quail and litter moisture (LM) were performed according to the methodology described in Experiment 1.

The glycerin was from BIOPAR ${ }^{\circledR}$-Bioenergia do Paraná LTDA., located in Rolândia, Paraná State. The values of $\mathrm{pH}$, crude protein, minerals, and gross energy were performed at the Food Analysis and Animal Nutrition Lab (LANA), according to the techniques described by Silva and Queiroz (2005). The total lipid content and methanol were determined in the Chemical and Fisic Departments, respectively, which belong to the Universidade Estadual de Maringá. Analysis of density, moisture content (Karl Fiher), and total glycerol were carried out at the Instituto de Tecnologia do Paraná (Tecpar). Sodium chloride was measured at the Analytical Lab of BIOPAR $\AA$.

The experimental diets were isonutritive and supplemented with industrial amino acids, lysine, threonine, and methionine. The levels of methionine and cystine:lysine were calculated in accordance with the requirements determined by Scherer (2009), corresponding to a methionine and cystine:lysine ratio of 0.84 and 0.88 for phases $1-14$ and 15-35 days, respectively; and the $\mathrm{Ca}$ and $\mathrm{P}$ requirement was determined by Silva et al. (2009). The chemical composition of feeds proposed by Rostagno et al. (2005) was used. The electrolyte balance of each diet (DEB) was determined as proposed by Mongin (1981). 


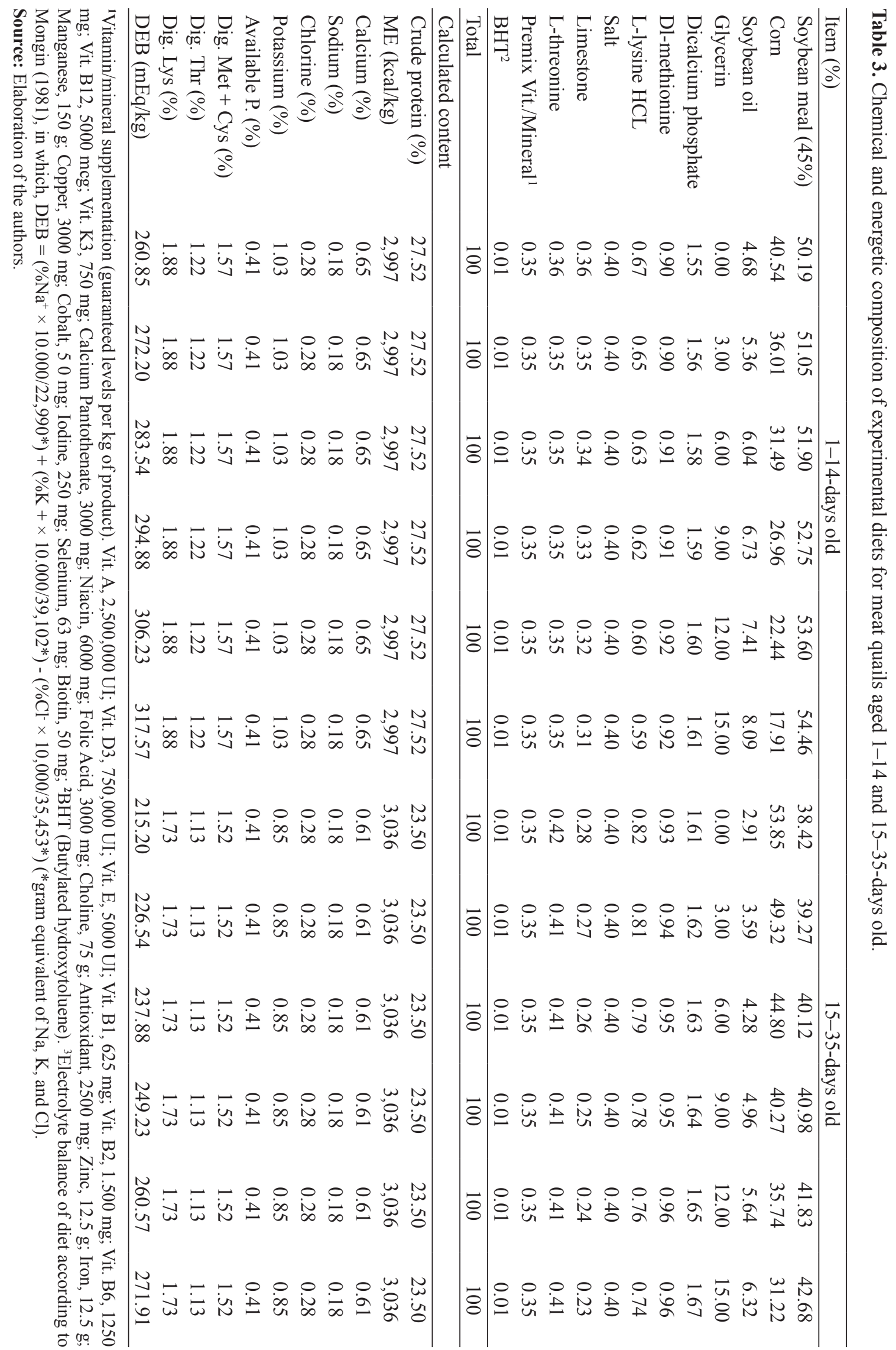


The temperatures were recorded inside and outside the boxes, at 08:00 $\mathrm{h}$ and 16:00 $\mathrm{h}$. The average, maximum, and minimum temperatures recorded in the first period (from 1 to 14 days) were $32.06^{\circ} \mathrm{C}$ and $27.05^{\circ} \mathrm{C}$ within the boxes, and $30.67^{\circ} \mathrm{C}$ and $25.27^{\circ} \mathrm{C}$ outside the boxes, respectively. In the second period (from 15 to 35 days), the temperatures were $30.54^{\circ} \mathrm{C}$ and $22.01^{\circ} \mathrm{C}$, and $20.70^{\circ} \mathrm{C}$ and $29.77^{\circ} \mathrm{C}$, respectively.

The quails were weighed weekly at the same time as the diets in order to calculate the body weight (BW), WG, feed intake (FI), feed conversion ratio (FCR), and body biomass accumulated (BBA).

The WG was determined by the difference between the mean final body weight and the initial body weight of quails in each experimental unit. The feed intake was determined by the difference between the diet provided and the leftover feed. The FCR was calculated by the difference between feed intake and $\mathrm{WG}$, and the BBA was calculated as a function of WG compared to the initial weight of the quails evaluated at the beginning of each stage. Mortalities were recorded daily and leftover feed was weighed and used to correct for feed intake.

At the end of the experimental period, litter samples were collected from all pens at three distinct points, avoiding the places next to feeders and nipple drinkers. The samples were identified, packed in plastic bags, and homogenized for further analysis of dry matter.

To determine the chemical body composition, five full quails per experimental unit at 14 days of age, and three quails at day 35 were used. After six hours of fasting, they were euthanized by decapitation between the occipital bone and atlas using scissors.

The quails (with feathers and viscera) were ground in an industrial meat grinder. The samples were weighed and homogenized, and placed in a forced air oven at $55^{\circ} \mathrm{C}$, for $72 \mathrm{~h}$ to perform the predrying, and were subsequently ground for analytical measurements. The chemical composition analysis of quail and LM were performed according to the methodology described in Experiment 1.

To determine the body protein deposition rate (PDR) and body fat deposition rate (FDR), the methodology described by Fraga (2002) was used. The PDR (g/day) at day 14 was calculated based on the mean PDR of quails that were slaughtered at birth, compared with quails slaughtered at the end of the experiment (day 14). From 15 to 35 days, it was considered that the initial amount of protein and fat was that determined by the average of all experimental treatments slaughtered at day 14 , and this was compared with that in quails slaughtered at the end of the experimental period (day 35). The retained body energy ( $\mathrm{kcal} / \mathrm{g}$ ) was determined according to Sakomura (2004).

To verify the economic feasibility (EF) of a diet including glycerin, the cost of feed per $\mathrm{kg}$ of weight gain (Yi), according to Bellaver et al. (1985) was initially determined. The index of economic efficiency (IEE) and the cost index (CI) were then calculated according to the method proposed by Gomes et al. (1991).

The costs of ingredients used in the preparation of experimental diets were obtained in Maringá at the time of the experiment, and were as follows: soybean meal, $\mathrm{R} \$ 0.66 / \mathrm{kg}$; corn grain, $\mathrm{R} \$ 0.26 / \mathrm{kg}$; soybean oil R\$1.79/kg; dicalcium phosphate, $\mathrm{R} \$$ 2.85/kg; limestone, R\$ 0.25/kg; L-Lysine, R\$ 8.94/ kg; DL-Methionine, R\$ 19.32/kg; L-Threonine, R\$ $12.44 / \mathrm{kg}$; vitamin and mineral premix $\mathrm{R} \$ 8.00 /$ kg; salt, R\$ 0.42/ kg; BHT, R\$ 11.20/kg; and semipurified glycerin $\mathrm{R} \$ 0.09 / \mathrm{kg}$.

Performance parameters, chemical body composition, carcass yield, and EF were subjected to polynomial regression analysis using data from diets containing $0 \%, 3 \%, 6 \%, 9 \%, 12 \%$, and $15 \%$ SG, using the statistical package Statistical Analysis System and Genetic-SAEG (UFV, 1997). The regression model chosen was the one that presented the best fit (R2). 


\section{Results and Discussion}

1. Experiment 1: The DM content of $S G$ was $85.68 \%$ (Table 4). Batista et al. (2013) observed values of $95.62 \%$ of DM for a semi-purified vegetable glycerin and Rostagno et al. (2011) proposed a DM content of $90.00 \%$.

According to Keer et al. (2011), adding a large volume of water into glycerin reduces its GE content, while the high fatty acids content increases its energetic value. This observation is consistent with results from our study, in which SG showed $3,217 \mathrm{kcal} / \mathrm{kg}$ of GE and $5.1 \%$ of ether extract.

The Ministério da Agricultura, Pecuária e Abastecimento (MAPA) established in September 2010, a normative authorizing the use of glycerin in animal feed; however, they emphasized that the glycerol and methanol content in a glycerin should be at least $80 \%$ and $150 \mathrm{mg} / \mathrm{kg}$, respectively. In the present study, the glycerol concentration in the glycerin was below this value whilst the concentration of methanol was above the recommended value.

The AMEn value of semi-purified glycerin was 2,476 kcal/kg FM (Figure 1) and the MCGE was $76.95 \%$. In a literature search, we found a high rate of GE metabolizability for glycerins. In this study, the high amount of water present in SG may have contributed to the low value of AMEn, and consequently to low values of MCGE. However, Bartelt and Schneider (2002) suggested that AME is reduced in the absence of renal reabsorption of glycerol. Gianfelici et al. (2011) reported that following the ingestion of high amounts of glycerol, there must be a level from which the metabolic capacity is overcome, leading to an increase in blood glycerol levels. Thus, once the capacity of the kidneys to reabsorb glucose is exceeded (KOOLMAN, ROEHM, 2005), or when glycerol is not absorbed due to the inactivity of glycerol kinase (MIN et al, 2010), presumably the excess glycerol is excreted in the urine following the inclusion of high levels in the diet (BARTELT; SCHENEIDER, 2002; DASARI, 2007; GIANFELICI, 2009).

Table 4. Chemical and energetic composition of semipurified glycerin.

\begin{tabular}{|c|c|}
\hline Nutrients & Semi-purified glycerin \\
\hline Humidity, $\%$ & 14.32 \\
\hline Dry matter, \% & 85.68 \\
\hline Gross energy, $\mathrm{kcal} / \mathrm{kg}(\mathrm{DM})$ & 3,217 \\
\hline Crude protein, $\%$ & 0.04 \\
\hline Ether extract, \% & 5.1 \\
\hline Glycerol, \% & 68.66 \\
\hline Methanol, mg/kg & 62,800 \\
\hline Organic matter $(\%)$ & 81.88 \\
\hline $\mathrm{OMNG}^{1}, \%$ & 13.22 \\
\hline Ash, $\%$ & 3.80 \\
\hline Sodium Chloride, $\%$ & 0.35 \\
\hline Calcium, ppm & 79.81 \\
\hline Phosphorus, ppm & 653.44 \\
\hline Potassium, $\%$ & 0.006 \\
\hline Sodium, \% & 1.04 \\
\hline Chloride, \% & 0.381 \\
\hline Manganese, $\mathrm{ppm}$ & 38.99 \\
\hline Copper, ppm & 0.532 \\
\hline Chromium, ppm & 8.571 \\
\hline Iron, ppm & 256.57 \\
\hline Zinc, ppm & 2.234 \\
\hline Manganese, ppm & 1.487 \\
\hline Aluminum, ppm & 13.86 \\
\hline Cobalt, ppm & 0.22 \\
\hline Molybdenum, ppm & 0 \\
\hline Lead, ppm & 0.526 \\
\hline $\mathrm{pH}$ & 1.67 \\
\hline Density, $\mathrm{kg} / \mathrm{m}^{3}$ & 1.189 \\
\hline
\end{tabular}

\begin{tabular}{lc}
\hline Fatty acids (\%) & \\
\hline Myristic (14:0) & $<0.1$ \\
Palmitic (16:0) & 36.83 \\
Palmitoleic (16:1 n - 7) & 10.04 \\
Stearic (18:0) & 22.07 \\
Oleic (18:1 $\mathrm{n}-9)$ & 16.96 \\
Vaccenic $(18: 1 \mathrm{n}-7)$ & $<0.1$ \\
Linoleic $(18: 2 \mathrm{n}-6)$ & 14.08 \\
Linolenic $(18: 3 \mathrm{n}-3)$ & $<0.1$ \\
\hline
\end{tabular}

${ }^{1}$ Organic matter not glycerin: $100-(\%$ glycerol $+\%$ humidity $+\%$ ash).

Source: Elaboration of the authors. 
Evaluating semi-purified glycerin derived from soybean oil, containing 3,862 $\mathrm{kcal} / \mathrm{kg}$ of GE and 92\% DM, Gianfelici et al. (2011) determined 3,276 $\mathrm{kcal} / \mathrm{kg}$ of AMEn (FM) for broilers that resulted in $84.82 \%$ of MCGE. According to the author, the minimum AMEn obtained was $1,527 \mathrm{kcal} / \mathrm{kg}$ when $5 \%$ glycerin was included in the diet. This shows that low inclusion levels of glycerin may not be adequate to determine its energy value, because can be underestimated.

Figure 1. Estimated value of $A M E n$ of $S G$ for growing meat quails, based on fresh matter. $S G=2,476 x ; R^{2}=0.66$.

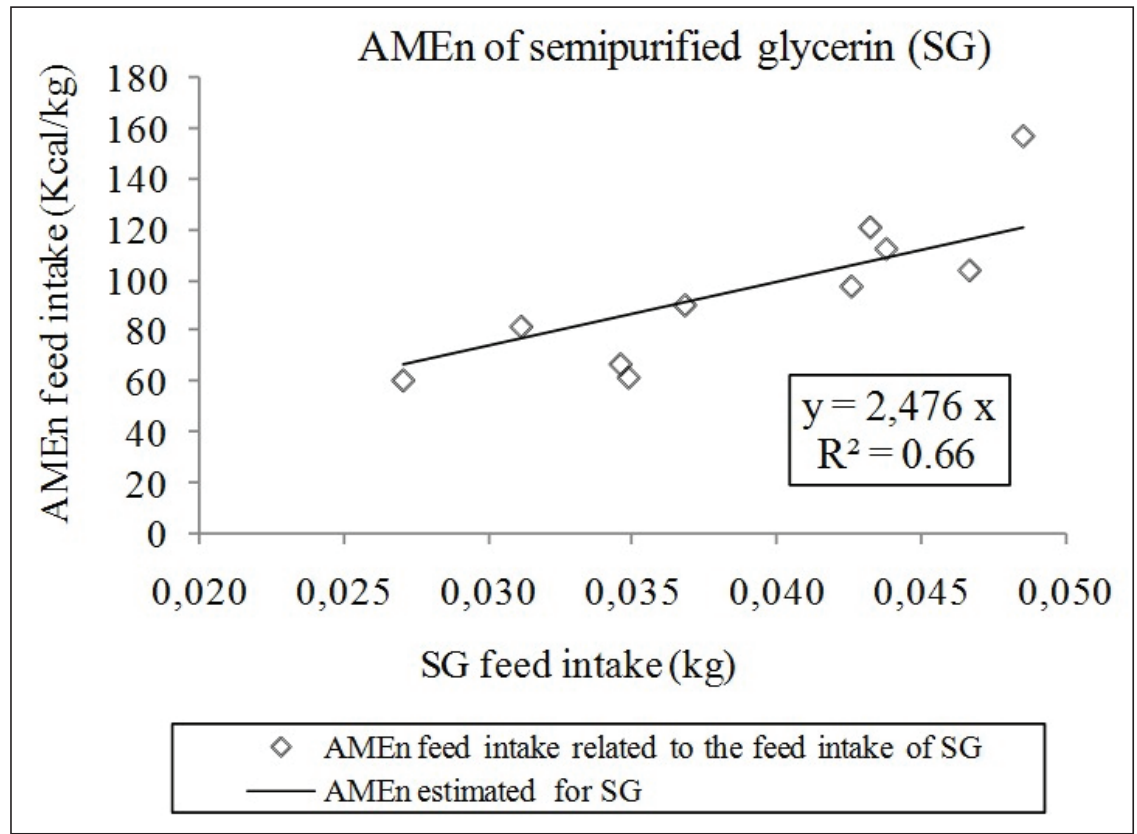

Source: Elaboration of the authors.

Working with the inclusion of $10 \%$ vegetable semi-purified glycerin (VSG) in quail diets, Batista et al. (2013) obtained a GE value of 3,585 $\mathrm{kcal} / \mathrm{kg}$, and an AMEn value of 3,068 $\mathrm{kcal} / \mathrm{kg}(\mathrm{FM})$, and the MCGE was $85.61 \%$. The authors obtained values of MCDM and MCOM of 88.44 and 90.99\%, respectively. In our study, the metabolizable dry matter (MDM) of SG was $71.37 \%$ and the MCDM was $83.30 \%\left(\mathrm{y}=83.30 \mathrm{x}, \mathrm{R}^{2}=0.68\right)$, whereas the metabolizable organic matter was $65.20 \%$ and the MCOM was 79.64\% (y=79.64x, $\left.\mathrm{R}^{2}=0.64\right)$.

The MCEE was 82.76\% $(y=82.76 x ; \mathrm{R} 2=$ 0.80 ). This relatively low value can be explained by the low EE concentration in SG (Table 4). Furthermore, according to Leeson and Summers (2001), the absorbability of the fatty acids, stearic and palmitic acid is low ( 0 and $2 \%$, respectively), and these are present at large proportions in glycerol (Table 4).

Recently, several studies have considered the use of glycerin as an energy source in feed for non-ruminant animals. However, variability in the composition of this by-product makes it difficult to determine an absolute energy value as well as the metabolizability of its nutrients. Furthermore, this is dependent on the species, age of the animals, and the levels included in the diets. The use of diets containing glycerin causes speciesspecific and organ-specific responses (MENTEN et al., 2010), and in this regard, further studies are needed, especially in relation to glycerol metabolism. 
Therefore, the use of glycerin in diet formulation requires caution since there is a lack of standardization in some parameters of chemical composition, considering that glycerin production is in the second plan. However, once it is feasible to use glycerin in animal nutrition, higher valorization and therefore more control over the quality of this by-product will occur.

2. Experiment 2 and 3: From 1 to 14 days of age, SG $(P>0.05)$ had no effect on performance variables (Table 5). Between 15 and 35 days there was a quadratic effect $(P<0.05)$ of SG levels on the $\mathrm{FCR}$ and BBA, in which, deriving the equations, we obtained the best estimates with the inclusion of $8.46 \%$ and $9.99 \%$ of SG, being 2.98 and 198.59 , for
FCR and BBA, respectively.

The BBA and LM increased linearly $(P<0.05)$ with inclusion levels of SG. Gianfelici (2009) attributed the increased loss of water, by chickens consuming glycerin, to increased production of urine due to low water absorption from the large intestine and increased renal excretion, since no abnormalities were found in the ileal contents. The author also found that water loss is enhanced when the amount of glycerin in the diet exceeds $7.5 \%$, which can be explained by saturation of glycerol in the organism, affecting its metabolism and increasing blood glycerol levels. The glycerol, as an osmotically active substance, can be excreted together with water.

Table 5. Performance and litter moisture of meat quails, fed diets containing SG from 1 to 14 and 15 to 35 -days old.

\begin{tabular}{|c|c|c|c|c|c|c|c|c|c|}
\hline \multirow{2}{*}{ Item } & \multicolumn{6}{|c|}{ Levels of semi-purified glycerin (\%), from day 1 to 14} & \multirow{2}{*}{$\mathrm{CV}$} & \multicolumn{2}{|c|}{$P$ value $^{1}$} \\
\hline & 0 & 3 & 6 & 9 & 12 & 15 & & $\mathrm{~L}$ & Q \\
\hline IW (g) & 9.27 & 9.28 & 9.25 & 9.28 & 9.26 & 9.25 & 0.26 & - & - \\
\hline $\mathrm{BW}(\mathrm{g})$ & 75.45 & 75.00 & 77.20 & 78.34 & 76.40 & 76.50 & 2.93 & 0.27 & 0.19 \\
\hline FI (g/bird) & 120.40 & 117.49 & 121.74 & 122.55 & 123.04 & 122.71 & 3.70 & 0.14 & 0.91 \\
\hline WG (g) & 66.17 & 65.71 & 67.94 & 69.06 & 67.14 & 67.25 & 3.34 & 0.26 & 0.19 \\
\hline FCR (g/g) & 1.82 & 1.79 & 1.79 & 1.78 & 1.83 & 1.83 & 3.63 & 0.59 & 0.27 \\
\hline $\mathrm{BBA}(\%)$ & 713.59 & 708.05 & 734.16 & 744.10 & 724.79 & 726.72 & 3.46 & 0.24 & 0.22 \\
\hline $\mathrm{LM}(\mathrm{g} / \mathrm{kg})$ & 17.70 & 17.06 & 19.38 & 14.70 & 19.11 & 21.56 & 20.55 & 0.20 & 0.18 \\
\hline \multirow{2}{*}{ Item } & \multicolumn{6}{|c|}{ Levels of semi-purified glycerin (\%), from day 15 to 35} & CV & \multicolumn{2}{|c|}{$P$ value $^{1}$} \\
\hline & 0 & 3 & 6 & 9 & 12 & 15 & $c r$ & $\mathrm{~L}$ & Q \\
\hline IW (g) & 76.80 & 76.58 & 76.40 & 75.94 & 76.44 & 76.33 & 0.88 & - & - \\
\hline BW (g) & 223.70 & 228.72 & 227.75 & 223.73 & 229.80 & 226.48 & 1.24 & 0.28 & 0.30 \\
\hline FI (g/bird) & 454.43 & 461.25 & 449.34 & 449.24 & 457.81 & 459.99 & 2.15 & 0.67 & 0.20 \\
\hline WG (g) & 146.89 & 152.14 & 151.35 & 147.79 & 153.36 & 150.16 & 1.64 & 0.13 & 0.15 \\
\hline $\mathrm{FCR}(\mathrm{g} / \mathrm{g})$ & 3.09 & 3.03 & 2.97 & 3.04 & 2.99 & 3.06 & 2.28 & 0.45 & $0.03^{2}$ \\
\hline $\mathrm{BBA}(\%)$ & 191.26 & 198.68 & 198.08 & 194.62 & 200.62 & 196.73 & 1.53 & $0.03^{3}$ & $0.04^{4}$ \\
\hline $\mathrm{LM}(\mathrm{g} / \mathrm{kg})$ & 19.14 & 19.36 & 19.77 & 19.94 & 22.32 & 22.01 & 7.50 & $0.0018^{5}$ & 0.47 \\
\hline
\end{tabular}

${ }^{1}$ Linear and quadratic effects related to the inclusion levels of semi-purified glycerin in diets; IW: initial body weight; BW: final body weight; FI: feed intake; WG: weight gain; FCR: feed conversion ratio; BBA: body biomass accumulated; LM: litter moisture; $\mathrm{CV}$ : coefficient variation (\%).

15 to 35 days: ${ }^{2} \mathrm{FCR}=3.0898-0.0237 \mathrm{SG}+0.0014 \mathrm{SG}^{2} ; \mathrm{R}^{2}=0.64 ; \mathrm{SG}=8.46 \% ;{ }^{3} \mathrm{BBA}=194.546+0.282554 \mathrm{SG} ; \mathrm{R}^{2}=0.23 ;{ }^{4} \mathrm{BBA}$ $=192.7+1.179 \mathrm{SG}-0.059 \mathrm{SG}^{2} ; \mathrm{R}^{2}=0.42 ; \mathrm{SG}=9.99 \% ;{ }^{5} \mathrm{LM}=18.750+0.2227 \mathrm{SG} ; \mathrm{R}^{2}=0.82$.

Source: Elaboration of the authors. 
Moreover, the presence of diarrhea has also been attributed to excess sodium or potassium ions in the feed. Cerrate et al. (2006) found that $10 \%$ glycerin increased the LM, and when subjected to chemical analysis, the diet with $10 \%$ of glycerin contained $0.15 \%$ more potassium, derived mainly from glycerin itself, more specifically, from potassium hydroxide, which is used as a catalyst during biodiesel production.

Lammers et al. (2008) noted increased moisture in excreta from laying hens when they used $15 \%$ crude glycerin (87\% glycerol, 9\% water, $0.03 \%$ methanol, $1.26 \% \mathrm{Na}$, and $3,625 \mathrm{kcal} / \mathrm{kg}$ of gross energy), emphasizing that the adjustment of sodium in relation to a basal diet containing $0.21 \%$ of the electrolyte was not performed. Barros et al. (2004) also found a linear increase in LM with the addition of sodium in broiler diets, stating that this response is related to the increased water intake by birds in an attempt to maintain body homeostasis.

As previously reported, adding salts to the diet causes increased thirst in birds, and therefore increases water consumption (MACARI, 1996). It is known that high levels of dietary glycerol may surpass the ability of the body to metabolize it, and is therefore excreted in the urine. It is known that glycerol is highly hydrophilic, thus the increased excretion of water can also be attributed to the strong affinity between water and glycerol.

Therefore, when body capacity to metabolize glycerol is saturated, it will be excreted, and therefore, instead promote increased fluid retention in the body, as suggested by Brisson et al. (2001) and Cerrate et al. (2006), it will promote an increase in the moisture of feces and consequently in LM.

Although we observed an increase in LM, from day 15 to 35 , no damage was observed to the animals during the study period. Moreover, in terms of nutrition, the sodium level in glycerin should be considered before proceeding with diet formulations, since the increase in LM is not desirable. According to Almeida (1986), LM can be maintained between $20 \%$ and $35 \%$, so the moisture content observed in this study is adequate.

Regarding the methanol, although the SG showed levels far above those recommended by the Ministério da Agricultura, Pecuária e Abastecimento (MAPA) no symptoms of toxicity were observed in the quails. According to reported studies (IPCS, 1997) showing that the toxicity of methanol or its metabolites is dependent on the dose and the body weight of the animals, it is important to consider the daily feed intake and methanol intake, according to the body weight of the animals.

Considering the chemical composition, from day 1 to 14 , regression analysis showed a linear effect $(P<0.05)$ of SG levels on the EE, PDR, FDR, and retained body energy (RBE) content. The same result was observed from day 15 to 35 , except for the PDR (Table 6). 
Table 6. Body chemical composition of meat quails fed diets containing semi-purified glycerin, from 1 to 14 and 15 to 35-days old.

\begin{tabular}{|c|c|c|c|c|c|c|c|c|c|}
\hline \multirow{2}{*}{ Item } & \multicolumn{6}{|c|}{ Levels of semi-purified glycerin (\%), from day 1 to 14} & \multirow{2}{*}{$\mathrm{CV}$} & \multicolumn{2}{|c|}{$P$ value $^{1}$} \\
\hline & 0 & 3 & 6 & 9 & 12 & 15 & & $\mathrm{~L}$ & Q \\
\hline Water $(\%)$ & 74.58 & 74.42 & 72.91 & 73.92 & 73.51 & 73.25 & 1.34 & 0.058 & 0.404 \\
\hline $\mathrm{CP}(\%)$ & 17.73 & 17.7 & 18.01 & 17.99 & 18.00 & 18.2 & 2.38 & 0.083 & 0.975 \\
\hline $\mathrm{EE}(\%)$ & 3.20 & 3.24 & 3.45 & 3.02 & 3.52 & 3.71 & 8.49 & $0.009^{2}$ & 0.305 \\
\hline Ash (\%) & 2.98 & 3.04 & 3.27 & 3.20 & 3.14 & 3.16 & 6.76 & 0.211 & 0.178 \\
\hline $\operatorname{PDR}(\mathrm{g} / \mathrm{d})$ & 0.86 & 0.85 & 0.89 & 0.91 & 0.88 & 0.90 & 3.52 & $0.027^{3}$ & 0.218 \\
\hline FDR $(g / d)$ & 0.13 & 0.14 & 0.15 & 0.13 & 0.16 & 0.17 & 12.34 & $0.011^{4}$ & 0.596 \\
\hline RBE (Kcal/g) & 6.11 & 6.13 & 6.54 & 6.42 & 6.50 & 6.70 & 4.25 & $0.003^{5}$ & 0.634 \\
\hline \multirow{2}{*}{ Item } & \multicolumn{6}{|c|}{ Levels of semi-purified glycerin (\%), from day 15 to 35} & \multirow{2}{*}{$\mathrm{CV}$} & \multicolumn{2}{|c|}{$P$ value $^{1}$} \\
\hline & 0 & 3 & 6 & 9 & 12 & 15 & & $\mathrm{~L}$ & Q \\
\hline Water $(\%)$ & 65.14 & 65.7 & 66.6 & 65.27 & 64.95 & 65.14 & 1.58 & 0.115 & 0.744 \\
\hline $\mathrm{CP}(\%)$ & 19.01 & 19.32 & 19.44 & 18.72 & 18.86 & 19.01 & 3.04 & 0.711 & 0.143 \\
\hline $\mathrm{EE}(\%)$ & 10.72 & 10.20 & 9.48 & 10.98 & 11.3 & 10.72 & 10.46 & $0.048^{6}$ & 0.541 \\
\hline Ash (\%) & 3.14 & 3.27 & 3.21 & 3.08 & 3.15 & 3.14 & 5.43 & 0.265 & 0.992 \\
\hline $\operatorname{PDR}(\mathrm{g} / \mathrm{d})$ & 1.40 & 1.40 & 1.37 & 1.36 & 1.35 & 1.40 & 5.44 & 0.817 & 0.216 \\
\hline $\operatorname{FDR}(\mathrm{g} / \mathrm{d})$ & 1.03 & 0.97 & 0.87 & 1.06 & 1.08 & 1.03 & 11.62 & $0.039^{7}$ & 0.582 \\
\hline RBE (Kcal/g) & 17.62 & 17.04 & 15.95 & 17.72 & 17.79 & 17.62 & 6.32 & $0.047^{8}$ & 0.957 \\
\hline
\end{tabular}

${ }^{1}$ Linear and quadratic effects related to the inclusion levels of semi-purified glycerin in the diets; CP: crude protein; EE: ether extract; PDR: protein deposition rate; FDR: fat deposition rate; RBE: retained body energy; CV: coefficient of variation (\%).

Day 1 to $14:{ }^{2} \mathrm{EE}=3.097+0.0330 \mathrm{SG} ; \mathrm{R}^{2}=0.49 ;{ }^{3} \mathrm{PDR}=0.861284+0.00297389 \mathrm{SG} ; \mathrm{R}^{2}=0.51{ }^{4} \mathrm{TDG}=0.133432+0.00207074 \mathrm{SG}$; $\mathrm{R}^{2}=0.62 ;{ }^{5} \mathrm{ECR}=6.12513+0.036235 \mathrm{SG} ; \mathrm{R}^{2}=0.79$

Day 15 to $35:{ }^{6} \mathrm{EE}=9.66306+0.0914257 \mathrm{SG} ; \mathrm{R}^{2}=0.42 ;{ }^{7} \mathrm{TDG}=0.906886+0.0101323 \mathrm{SG} ; \mathrm{R}^{2}=0.36 ;{ }^{8} \mathrm{ECR}=16.2950+$ $0.0910045 \mathrm{SG} ; \mathrm{R}^{2}=0.31$;

Source: Elaboration of the authors.

Conversely, Batista (2010) found no such effect of glycerin on the EE, ash, PDR, FDR, and RBE. This is consistent with a study by Gianfelici (2009), which did not detect any changes in $\mathrm{CP}$, ash, and fat content of broiler carcasses, suggesting that no protein synthesis was stimulated, and as suggested by Lin, Romsons and Leveille (1976), also no triglyceride synthesis as a source of glycerol-3phosphate or acetyl-CoA (Acetyl Coenzyme-a), which are required for the synthesis of fatty acids. Guerra et al. (2011) evaluated crude glycerin (CG) levels in broilers from 22 to 42-days old, and found that abdominal fat decreased linearly according to increasing levels of CG in the diets. In this study, the amount of soybean oil added to the diet decreased according to the level of CG included in the diets due to its high-energy content. The authors suggested that these results might be due to overestimation of the energy intake of CG. However, previous studies have reported that glycerol does not stimulate fatty acids synthesis; therefore, these results may also have occurred due to the reduction of soybean oil in the diets.

Carmona and Freedland (1989) observed that glycerol supplementation impaired lipogenic activity (fatty acids synthesis) in rats, and they attributed this anti lipogenic effect of glycerol to the large decrease in cytosolic pyruvate levels that may results from an increase in the NADH/NAD ratio. The authors further pointed that reduced pyruvate may limit citrate production, and consequently the amount of acetyl units available for fatty acids synthesis.

Thus, the results of this study cannot be directly attributed to SG, but indirectly, by its low energetic 
value, because as SG levels increased in the diet, there was the need for greater addition of soybean oil. Essary et al. (1965) showed that for every 2\% of oil added to the diet, there was a corresponding increase of $0.6 \%$ in carcass fat. Urban (2006) observed that feed containing a greater proportion of soybean oil (7\%) led to broiler chicken carcasses with a high lipid content, and for each $2 \%$ of oil added to the diet, there was a corresponding increase of $1.16 \%$ in the carcass fat. According to Hurwitz et al. (1987) the high correlation between the levels of oil in the diet and body fat deposition in birds, occurs due to their ability to transfer fatty acids from the diet to adipose tissue, with no need of synthesis by the liver.

Considering the carcass yield, in this study the breast weight and breast meat yield increased linearly $(P<0.05)$ with the inclusion levels of SG (Table 7). The glycerol associated water intake leads to an increased volume of water in the body, maintaining higher hydration by reducing the renal elimination rate of water from the body (BRISSON et al. 2001). This was confirmed by Cerrate et al. (2006), who, using diets containing 2.5 and $5 \%$ of glycerin, found an increase in breast yield of broilers, suggesting improvement in water absorption, as emphasized previously. However, the authors noted that after 14 days of age, the inclusion of $10 \%$ glycerin in broiler diet caused a significant reduction in carcass traits, breast weight, wing, thigh, and leg. Moreover, Guerra et al. (2011) evaluated the levels of CG in broiler feed, from 22 to 42 days of age, and observed no effect on carcass traits.

Some studies have suggested that glycerol can contribute to protein synthesis by reducing the activity of phosphoenol pyruvate carboxykinase, thus, sparing the gluconeogenic amino acids (CRYER, BARTLEY, 1973; YOUNG; SHRAGO; LARDY, 1964). However, the results of this study cannot be attributed to these factors, since no differences were observed in the percentage of $\mathrm{CP}$ and PDR in the period from 15 to 35 days.

Considering the economic feasibility (Table 8), the costs per kilogram of feed (DC) containing SG were high, ranging from $\mathrm{R} \$ 0.88 / \mathrm{kg}$ for $3 \%$ level to $\mathrm{R} \$ 0.91 / \mathrm{kg}$ for $15 \%$ level of SG, from 1 to 14 days old, and from $\mathrm{R} \$ 0.84 / \mathrm{kg}$ to $\mathrm{R} \$ 0.87 / \mathrm{kg}$ between 15 to 35 days old, respectively.

Table 7. Average values of body weight, yield and carcass cuts of meat quails, fed increasing levels of SG in the period from 15 to 35 -days old.

\begin{tabular}{|c|c|c|c|c|c|c|c|c|c|}
\hline \multirow{2}{*}{ Item } & \multicolumn{6}{|c|}{ Levels of semi-purified glycerin (\%) } & \multirow{2}{*}{$\mathrm{CV}$} & \multicolumn{2}{|c|}{$P$ value $^{1}$} \\
\hline & 0 & 3 & 6 & 9 & 12 & 15 & & $\mathrm{~L}$ & $\mathrm{Q}$ \\
\hline $\mathrm{BW}(\mathrm{g})$ & 211.21 & 217.53 & 219.07 & 215.51 & 224.8 & 217.32 & 4.30 & - & - \\
\hline $\mathrm{CW}(\mathrm{g})$ & 138.08 & 140.02 & 143.82 & 138.97 & 146.96 & 142.6 & 5.45 & 0.249 & 0.683 \\
\hline CT (g) & 65.31 & 64.36 & 65.66 & 64.51 & 65.36 & 65.57 & 2.51 & 0.650 & 0.599 \\
\hline BRW (g) & 57.49 & 61.33 & 61.67 & 61.74 & 66.52 & 63.28 & 7.57 & $0.035^{2}$ & 0.422 \\
\hline BMY (g) & 41.64 & 43.78 & 42.9 & 44.39 & 45.28 & 44.3 & 4.17 & $0.020^{3}$ & 0.319 \\
\hline LW (g) & 32.78 & 33.17 & 34.51 & 33.44 & 34.82 & 33.35 & 7.36 & 0.524 & 0.431 \\
\hline LY $(g)$ & 23.82 & 23.7 & 23.97 & 24.11 & 23.67 & 23.37 & 5.00 & 0.671 & 0.502 \\
\hline AFW (g) & 1.26 & 1.54 & 1.75 & 1.97 & 2.01 & 1.42 & 52.69 & 0.511 & 0.224 \\
\hline $\operatorname{AFY}(\mathrm{g})$ & 0.59 & 0.58 & 0.81 & 0.93 & 0.89 & 0.66 & 54.59 & 0.439 & 0.268 \\
\hline
\end{tabular}

${ }^{1}$ Linear and quadratic effects related to the inclusion levels of semi-purified glycerin in the diets; BW: body weight; CW: carcass weight; CT: carcass traits; BRW: breast weight; BMY: breast meat yield; LW: leg weight; LY: leg yield; AFW: abdominal fat weight; RGA: abdominal fat yield. CV: coefficient of variation (\%).

${ }^{2} \mathrm{BRW}=58.8198+0.4245 \mathrm{SG} ; \mathrm{R}^{2}=0.66 ;{ }^{3} \mathrm{BMY}=42.3351+0.1839 \mathrm{SG} ; \mathrm{R}^{2}=0.65$;

Source: Elaboration of the authors. 
Table 8. Economic feasibility of the inclusion of SG in the diets of meat quails, in the period of 1 to 14 days and 15 to 35-days old.

\begin{tabular}{|c|c|c|c|c|c|c|c|c|c|}
\hline \multirow[b]{2}{*}{ Item } & \multicolumn{6}{|c|}{ Levels of semi-purified glycerin (\%), from day 1 to 14} & \multirow[b]{2}{*}{$\mathrm{CV}$} & \multicolumn{2}{|c|}{$P$ value $^{1}$} \\
\hline & 0 & 3 & 6 & 9 & 12 & 15 & & $\mathrm{~L}$ & Q \\
\hline $\mathrm{DC}(\mathrm{R} \$ / \mathrm{kg})$ & 0.87 & 0.88 & 0.89 & 0.90 & 0.91 & 0.91 & & & \\
\hline Yi (R\$/kg BW) & 1.59 & 1.58 & 1.59 & 1.60 & 1.66 & 1.67 & 3.66 & $0.015^{2}$ & 0.272 \\
\hline $\operatorname{IEE}(\%)$ & 99.22 & 100.00 & 98.91 & 98.86 & 94.98 & 94.37 & & & \\
\hline \multirow[t]{2}{*}{$\mathrm{CI}(\%)$} & 100.78 & 100.00 & 101.10 & 101.15 & 105.28 & 105.96 & & & \\
\hline & \multicolumn{6}{|c|}{ Levels of semi-purified glycerin (\%), from day 15 to 35} & & \multicolumn{2}{|c|}{$P$ value ${ }^{1}$} \\
\hline Item & 0 & 3 & 6 & 9 & 12 & 15 & $\mathrm{CV}$ & $\mathrm{L}$ & Q \\
\hline $\mathrm{DC}(\mathrm{R} \$ / \mathrm{kg})$ & 0.83 & 0.84 & 0.85 & 0.85 & 0.86 & 0.87 & & & \\
\hline Yi (R\$/kg BW) & 2.56 & 2.54 & 2.51 & 2.60 & 2.57 & 2.67 & 2.26 & $0.010^{3}$ & 0.090 \\
\hline IEE (\%) & 97.91 & 98.93 & 100.00 & 96.74 & 97.58 & 94.19 & & & \\
\hline CI $(\%)$ & 102.13 & 101.08 & 100.00 & 103.97 & 102.48 & 106.17 & & & \\
\hline
\end{tabular}

${ }^{1}$ Linear and quadratic effects related to the inclusion levels of semi-purified glycerin in the diets; DC: diet cost (R\$/kg); Yi: cost per kg of live weight produced (R $\$ / \mathrm{kg} P \mathrm{PV})$; IEE: index of economic efficiency; IC: cost index; CV: coefficient of variation (\%).

Day 1 to $14:{ }^{2} \mathrm{Yi}=1.5677+0.0062 \mathrm{SG} ; \mathrm{R}^{2}=0.76$

Day 15 to $35:{ }^{3} \mathrm{Yi}=2.5249+0.0066 \mathrm{SG} ; \mathrm{R}^{2}=0.49$;

Source: Elaboration of the authors.

These results can be justified by the requirement of increased oil addition in the diets containing SG. These results are similar to those obtained by Batista (2010), in which evaluating vegetable crude glycerin and vegetable semi-purified glycerin, noted higher dietary costs when semi-purified glycerin was used, which provided the smaller ME value.

The regression analyses show that the cost per kilogram of produced body weight (Yi) increased linearly $(\mathrm{P}<0.05)$ with inclusion levels of $\mathrm{SG}$ on two phases evaluated, and revealed an increase in production costs. These results can be justified by the increased on the diet costs.

It can be concluded that the estimated value of nitrogen-corrected apparent metabolizable energy of semi-purified glycerin, for meat quails was, $2,476 \mathrm{kcal} / \mathrm{kg}$, and the metabolizability coefficient of gross energy was $76.95 \%$. Considering the performance data, up to $15 \%$ semi-purified glycerin can be used in meat quail diets, from 1 to 14- days old, and on the phase from 15 to 35 -days old, up to the $10 \%$ level. From an economic point of view, its use will depend on the costs of other ingredients in the diets, since these vary.

\section{Acknowledgment}

At the Conselho Nacional de Desenvolvimento Científico e Tecnológico, for the scholarship and to the company Biopar-Bioenergia do Paraná, for the donation of glycerin.

\section{References}

ALMEIDA, M. A. C. Fatores que afetam a umidade da cama. Avicultura Industrial, São Paulo, v. 76, n. 919, p. 16-18, 1986.

BARTELT, J.; SCHNEIDER, D. Investigation on the energy value of glycerol in the feeding of poultry and pigs. In: Union for the promotion of oilseeds- schriften heft 17. Berlin: Union Zur Förderung Von Oel-Und Proteinplafalzen E.V., Berlin, Germany, 2002. p. 15-36.

BARROS, J. M. S.; GOMES, P. C.; ALBINO, L. F. T.; ROSTAGNO, H. S.; COSTA, L. F. Exigência de sódio para frangos de corte nas fases de crescimento (22 a 42 dias) e final (43 a 53 dias). Revista Brasileira de Zootecnia, v. 33, n. 6, p. 1721-1733, 2004. Suplemento 1.

BATISTA, E.; FURLAN, A. C.; TON, A. P. S.; PASQUETTI, T. J.; QUADROS, T. C. O.; GRIESER, D. O.; ZANCANELA, V. Avaliação nutricional da glicerina vegetal semipurificada para codornas de corte. Arquivo Brasileiro de Medicina Veterinária e Zootecnia, Belo Horizonte, v. 65, n. 6, p. 1783-1791, 2013. 
BATISTA, E. Avaliação nutricional de glicerol para codornas de corte. 2010. Dissertação (Mestrado em Zootecnia) - Universidade Estadual de Maringá, Maringá.

BELlAVER, C.; FIALHO, E. T.; PROTAS, J. F. S.; GOMES, P. C. Radícula de malte na alimentação de suínos em crescimento e terminação. Pesquisa Agropecuária Brasileira, Brasília, v. 20, n. 8, p. 969-974, 1985.

BRISSON, D.; VOHL, M. C.; ST-PIERRE, J.; HUDSON, T. J.; GAUDET, D. Glycerol: a neglected variable in metabolic process? Bio Essays, Weinheim, v. 23, n. 6, p. 534-542, 2001.

CARMONA, A.; FREEDLAND, R. A. Effect of glycerol and dihydroxyacetone on hepatic lipogenesis. Archives of Biochemistry and Biophysics, v. 271, n. 1, p. 130-138, maio 1989.

CERRATE, S.; YAN, F.; WANG, Z.; COTO, C.; SACAKLI, P.; WALDROUP, P. W. Evaluation of glycerine from biodiesel production as a feed ingredient for broilers. International Journal of Poultry Science, Faisalabad, v. 11, n. 5, p. 1001-1007, 2006.

CRYER, A.; BARTLEY, W. Studies of the adaptation of rats to a diet high in glycerol. International Journal of Biochemistry, Nedlands, v. 4, n. 21, p. 293-308, 1973.

DASARI, M. Crude glycerol potential described. Feedstuffs, St. Charles, v. 79, n. 43, p. 1-3, 2007.

ESSARY, E. O.; DAWSON, L. E.; WISMANN, E. L.; HOLMES, C. E. Influence of different levels of fat and protein in broiler rations on live weight, dressing percentage and specific gravity of carcass. Poultry Science, Champaign, v. 44, n. 1, p. 34-35, 1965.

FRAGA, A. L. Exigência de lisina para suínos em fase inicial (15-30 kg), de dois grupos genéticos, em rações formuladas de acordo com o conceito de proteína ideal. 2002. Dissertação (Mestrado em Zootecnia) Universidade Estadual de Maringá, Maringá.

GIANFELICI, M. F. Uso de glicerol como fonte de energia para frangos de corte. 2009. Dissertação (Mestrado em Zootecnia) - Universidade Federal do Rio Grande do Sul, Faculdade de Agronomia, Porto Alegre.

GIANFELICI, M. F.; RIBEIRO, A. M. L.; PENZ JUNIOR, A. M.; KESSLER, A. M.; VIEIRA, M. M. Determination of apparent metabolizable energy of crude glycerin in broilers chickens. Brazilian Journal of Poultry Science, Campinas, v. 13, n. 4, p. 255-258, out./ dez. 2011.

GOMES, M. F. M.; BARBOSA, H. P.; FIALHO, E. T.; FERREIRA, A. S.; DE LIMA, G. J. M. M. Análise econômica da utilização do triguilho para suínos. [S.1]: EMBRAPA - Centro Nacional de Pesquisa de Suínos e
Aves, 1991. p. 1-2. (Comunicado técnico, 179).

GOMES, J. D. F; FUKUSHIMA, R. S.; PUTRINO, S. M.; GROSSKLAUS, C.; LIMA, G. J. M. M. Efeitos do incremento da fibra em detergente neutro na dieta de suínos sobre a morfologia dos órgãos digestivos e não digestivos. Brazilian Journal of Veterinary Research and Animal Science, São Paulo, v. 43, n. 2, p. 202-209, 2006.

GUERRA, R. L. H.; MURAKAMI, A. E.; GARCIA, A. F. Q. M.; URGNANI, F. J.; MOREIRA, I.; PICOLI, K. P. Glicerina bruta mista na alimentação de frangos de corte (1 a 42 dias). Revista Brasileira de Saúde e Produção Animal, Salvador, v. 12, n. 4, p. 1038-1050, out./dez. 2011.

HURWITZ, S.; PLAVNIK, I.; BEN-GAL, I.; BARTOV, I. Response of growing turkeys to dietary fat. Poultry Science, Champaign, v. 67, n. 3, p. 420-426, 1987.

INTERNATIONAL PROGRAMME ON CHEMICAL SAFETY - IPCS. Environmental health criteria 196 methanol. Geneva: WHO; 1997. Available at: Disponível em: http://www.inchem.org/documents/ehc/ehc/ehc196. htm>. Accessed at: 07 fev. 2011.

KERR, B. J.; SHURSON, G. C.; JOHNSTON, L. J.; DOZIER, W. A. Utilization of crude glycerin in nonruminants. In: MONTERO, G.; STOYTCHEVA, M. (Ed.). Biodiesel - quality, emissions and by-products. [S.1.: s.n], 2011. p. 365-380. Available at: <http://www. intechopen.com/books/biodiesel-quality-emissionsand-by-products/utilization-of-crude-glycerin-innonruminants>. Accessed at: 02 abr. 2014.

KOOLMAN, J.; ROEHM, K. H. Color atlas of biochemistry. 2. ed. New York: Thieme Stutgart, 2005. $467 \mathrm{p}$.

LAMMERS, P. J.; KERR, B. J.; HONEYMAN, M. S.; STALDER, K.; DOZIER, W. A.; WEBER, T. E.; KIDD, M. T.; BREGENDHAL, K. Nitrogen-corrected apparent metabolizable energy value of crude glycerol for laying hens. Poultry Science, Champaign, v. 87, n. 1, p. 104107, 2008.

LEESON, S.; SUMMERS, J. D. Scott's nutrition of the chicken. 4. ed. Guelph: University Books, 2001. 591 p.

LIN, M. H.; ROMSONS, R. R.; LEVEILLE, A. G. Effect of glycerol on lipogenic enzyme activities and on fatty acid synthesis in the rat and chicken. Journal of Nutrition, Bethesda, v. 106, n. 11, p. 1668-1677, 1976.

MACARI, M. Água na agricultura industrial. Jaboticabal: Unesp-Funep, 1996. 128 p.

MATTERSON, L. D.; POTTER, L. M.; STUTZ, M. W.; SINGSEN, E. P. The metabolizable energy of feed ingredients for chickens. University of Connecticut, 
Agricultural Experiment Station, Research Report, Storrs, Connecticut, v. 7, n. 1, p. 11-14, 1965.

MENTEN, J. F. M.; PEREIRA, P. W. Z.; RACANICCI, A. M. C. Avaliação da glicerina proveniente do biodiesel como ingrediente para rações de frangos de corte. In: CONFERÊNCIA APINCO 2008 DE CIÊNCIA E TECNOLOGIA AVÍCOLAS, 2008, Santos. Anais... Campinas: Fundação APINCO de Ciência e Tecnologia Avícola, 2008. p. 66.

MENTEN, J. F. M.; ZAVARISE, K. C. SILVA, C. L. S. Biodiesel: oportunidades do uso de glicerina na nutrição de aves. In: CONGRESSO LATINO AMERICANO DE NUTRIÇÃO ANIMAL - CLANA CBNA/AMENA, 4., 2010. Estância de São Pedro. Anais... Estância de São Pedro: CLANA, 2010. p. 43-56.

MIN, Y. N.; YAN, F.; LIU, F. Z.; COTO, C.; WALDROUP, P. W. Glycerin-a new energy source for poultry. International Journal of Poultry Science, Faisalabad, Pakistan, v. 9, n. 1, p. 1-4, 2010.

MONGIN, P. Recent advances in dietary ânion-cátion balance: applications in poultry. Proceedings of the Nutrition Society, Dublin, v. 40, n. 1, p. 285-294, 1981.

MURAKAMI, A. E.; FURLAN, A. C. Pesquisas na nutrição e alimentação de codornas em postura no Brasil. In: SIMPÓSIO INTERNACIONAL DE COTURNICULTURA, 1., 2002, Lavras. Anais... Lavras: Universidade Federal de Lavras, 2002. p. 113-120.

NETER, J.; WASSERMAN, W. Applied linear statistical models. [S.1.: s.n], 1974. 842 p.

ROSTAGNO, H. S.; ALBINO, L. F. T.; DONZELE, J. L.; GOMES, P. C.; OLIVEIRA, R. F.; LOPES, D. C.; FERREIRA, A. S.; BARRETO, S. L. T. Tabelas brasileiras para aves e suinos: composição de alimentos e exigências nutricionais. 2. ed. Viçosa: UFV, Departamento de Zootecnia, 2005. 186 p.
ROSTAGNO, H. S.; ALBINO, L. F. T.; DONZELE, J. L.; GOMES, P. C.; OLIVEIRA, R. F.; LOPES, D. C.; FERREIRA, A. S.; BARRETO, S. L. T.; EUCLIDES, R. F. Tabelas brasileiras para aves e suínos: composição de alimentos e exigências nutricionais. 3. ed. Viçosa: UFV, Departamento de Zootecnia, 2011. 252 p.

SAKOMURA, N. K. Modeling energy utilization in broiler breeders, laying hens and broilers. Revista Brasileira de Ciência Avícola. Campinas, v. 6, n. 1, p. 1-11, 2004.

SCHERER, C. Exigência nutricional de energia metabolizável, lisina digestivel e metionina + cistina digestível para codornas de corte em fase de crescimento. 2009. Tese (Doutorado em Zootecnia) - Universidade Estadual de Maringá, Maringá.

SILVA, R. M.; FURLAN, A. C.; TON,A.P. S.; MARTINS, E. N.; SCHERER, C.; MURAKAMI, A. E. Exigências nutricionais de cálcio e fósforo de codornas de corte em crescimento. Revista Brasileira de Zootecnia, v. 38, n. 8 , p. 1509-1517, 2009.

SILVA, D. J.; QUEIROZ, J. S. Análise de alimentos: métodos químicos e biológicos. 2. ed. Viçosa: Imprensa Universitária, 2005. 235 p.

UNIVERSIDADE FEDERAL DE VIÇOSA - UFV. Sistemas de análises estatísticas e genéticas - SAEG. versão 7.1. Viçosa, MG, 1997. 150 p.

URBANO, T. Niveis de inclusão de óleo de soja na ração de frangos de corte criados em temperaturas termoneutra e quente. 2006. Dissertação (Mestrado em Zootecnia) - Universidade Estadual Paulista, Jaboticabal.

YOUNG, J. W.; SHRAGO, E.; LARDY, H. A. Metabolic Control of enzymes involved in lipogenesis and gluconeogenesis. Biochemistry, Nashville, Tennessee, v. 3, n. 11, p. 1687-1692, nov. 1964. 